\title{
Author Correction: Competition between crystal and fibril formation in molecular mutations of amyloidogenic peptides
}

\author{
Nicholas P. Reynolds (10 1, Jozef Adamcik², Joshua T. Berryman², Stephan Handschin², \\ Ali Asghar Hakami Zanjani ${ }^{3}$, Wen $\mathrm{Li}^{4}$, Kun Liu ${ }^{4}$, Afang Zhang ${ }^{4} \&$ Raffaele Mezzenga ${ }^{2,5}$
}

Correction to: Nature Communications https://doi.org/10.1038/s41467-017-01424-4, published online: 20 Jul 2017

The original version of this article contained an error in Fig. 5c. The label for the back series of columns was incorrectly given as ' $1.5 \mathrm{mM} \mathrm{pH} 2$ ', rather than the correct ' $1.5 \mathrm{mM} \mathrm{pH} \mathrm{7'.} \mathrm{This} \mathrm{has} \mathrm{now} \mathrm{been} \mathrm{corrected} \mathrm{in} \mathrm{both} \mathrm{the} \mathrm{PDF} \mathrm{and} \mathrm{HTML} \mathrm{versions} \mathrm{of} \mathrm{the} \mathrm{article.}$

Published online: 20 December 2017

\begin{abstract}
(c) (i) Open Access This article is licensed under a Creative Commons Attribution 4.0 International License, which permits use, sharing, adaptation, distribution and reproduction in any medium or format, as long as you give appropriate credit to the original author(s) and the source, provide a link to the Creative Commons license, and indicate if changes were made. The images or other third party material in this article are included in the article's Creative Commons license, unless indicated otherwise in a credit line to the material. If material is not included in the article's Creative Commons license and your intended use is not permitted by statutory regulation or exceeds the permitted use, you will need to obtain permission directly from the copyright holder. To view a copy of this license, visit http://creativecommons.org/licenses/by/4.0/.
\end{abstract}

(C) The Author(s) 2017

\footnotetext{
${ }^{1}$ Swinburne University of Technology, ARC Training Centre for Biodevices, Faculty of Science, Engineering and Technology, John Street, Melbourne, VIC 3122, Australia. ${ }^{2}$ ETH Zurich, Department of Health Science \& Technology, Schmelzbergstrasse 9, LFO, E23, 8092 Zürich, Switzerland. ${ }^{3}$ University of Luxembourg, Department of Physics and Materials Science, 162a Avenue de la Faïencerie, Luxembourg City L-1511, Luxembourg. ${ }^{4}$ Shanghai University, Department of Polymer Materials, Nanchen Street 333, Shanghai 200444, China. ${ }^{5}$ ETH Zurich, Department of Materials, Wolfgang-Pauli-Strasse 10, 8093 Zurich, Switzerland. Nicholas P. Reynolds, Jozef Adamcik and Joshua T. Berryman contributed equally to this work. Correspondence and requests for materials should be addressed to R.M. (email: raffaele.mezzenga@hest.ethz.ch)
} 